Vol. 1, No. 2, Desember 2020

\title{
SPEKTA
}

Jurnal Pengabdian Kepada Masyarakat : Teknologi dan Aplikasi

Journal homepage :

http://journal2.uad.ac.id/index.php/spekta

\section{EDUCATING BORDER DWELLERS TO PROMOTE PEACE AND SECURITY IN AN ELECTORAL PROCESS: PERCEPTION OF COMMUNITY MEMBERS', ZAMFARA STATE}

Bello Bolanle Muhinat

Department of Social Sciences Education, Faculty of Education, University of Ilorin, Nigeria

\section{INFO ARTIKEL}

Diterima: 14 September, 2020

Direvisi: 7 Oktober, 2020

Disetujui: 9 Oktober, 2020

Keywords:

Border;

Dwellers;

Peace;

Security and

Electoral Process.

\begin{abstract}
This study examined the perception of border community members on educating border dwellers so as to promote peace and security in an electoral process in Nigeria. The study adopted a descriptive survey design, with a target population of This study examined the perception of border community members on educating border dwellers so as to promote peace and security in an electoral process in Nigeria. The study adopted a descriptive survey design, with a target population of Zamfara state's Zurmi Local Government Areas border communities of Gurbin Bore. Researcher's designed questionnaire with psychometric properties of content validity of 0.61 and a reliability index of 0.87 was used to elicit the needed data from the respondents. A multistage sampling technique was used to sample 384 respondents. The research questions and hypotheses were analyzed using mean score and $t$-test. The finding revealed that all the community members perceive educating them as a welcome development that would help in breeding youth that is needed in an electoral process. It was thus, recommended among others that, the government should provide qualitative education for people residing in the international border areas.
\end{abstract}

\section{INTRODUCTION}

The electoral process that provides the electorate with the institutional framework for choosing members through a successful free and fair election is a primary determinant of democracy. Basically, elections are the only acceptable institutionalized process that allows all acknowledged citizens of a democratic society to choose their representatives. It has been a general fact that today's elections in Nigeria have been marred by unprecedented misuse of the electoral process

\footnotetext{
* Corresponding author. $\mathrm{T}$

E-mail address: bello.mb@unilorin.edu.ng

https://doi.org/10.12928/spekta.v1i2.2793
} 
in the form of election rigging,ballot snatching, polling center killing, voting buying, an $\mathrm{d}$ much more, of which the youth has been a major tool. By youth we mean, a young man or woman, it a collection of young people. Nigeria's population is largely young people (Olujide, 2008). According to Nigeria's National Youth Development Policy (Olujide, 2008), the youth comprises all young people between the ages of 18 and 45 who are residents of the Federal Republic of Nigeria. This group represents the most active segment of the population, the most dynamic, the most impulsive and yet the most vulnerable of the population. To the United Nations (2012) youth is considered to be a time in the life of an individual running between the end of childhood and entrance into the world of work. Commitment to youth education has been reinforced by the resolution of various international organizations that draw attention to the need to tackle the problems of youth education in a concrete way. These young people need education and training in order to develop intellectually, morally, socially and with adequate skills in order to face a rapidly developing technological world (Laogun, 2002)

According to the NIC report, the protruding youth population is a demographic feature linked to the "emergence of political violence and civil conflict". In the course of elective politics and governance, youths are either side-lined or let off or when they are involved at all, they are mainly misused and abused to achieve the inordinate and perverse political ambition of the norm less, lawless and self-centered section of the Nigerian political class. (Preyekuro, 2011).

Youth all over the World are fondly called leaders of tomorrow. Depending on the individual or in some cases the community, this energy is either used positively or negatively. This is the time of intense interest in spiritual action and inexperience, according to Ekwuruke (2007). Most of these young people who have dropped out of villages or rural schools often end up in urban centers in search of menial jobs. Some other end-ups on the streets, highway junctions, and traffic hawking various items as "mobile supermarkets" (Ekwuruke, 2007), all of which further contributed to the ongoing problem of youth violence in an electoral process that continues to involve most Nigerian youth today. Young people in every society are seen as tomorrow's leaders, which means that they are the human resources of a nation that is also seen as the nation's growth engine. However, these must be adequately developed and used effectively. Likewise, it is generally believed that if human resources are equipped with qualitative education, the foundation of any true progress in a community must be the presence of peace and security. Reasoning in this way, Aliu (2001), who sees education, has been able to provide its beneficiaries with a desire to learn life-long awareness, beliefs, attitudes, abilities, and skills that one needs to promote peace and security at all times in the community in which he lives.

By educating a person one tries to give some desirable knowledge, understanding, skills, interests, attitudes and critical thinking to a man (Denga, 1999). In other words, man acquires knowledge of history, geography, arithmetics, languages, and science. He gains some understanding of the deeper things in life, the complex relationships between people, the connection between cause and effect, and so on. He gets some skills in writing, speaking, calculating, drawing, operating some equipment, etc. He establishes those beliefs and attitudes towards social work, democratic living, cooperative living, respect for authority and other members of society, managing the society's human and material resources to facilitate peaceful living. Training in Swastik's word (2014) helps a man to think critically about different issues in life and make decisions that are free of bias and discrimination, superstitions and blind beliefs. 
Therefore, through the educational process, he will learn all these attributes of head, hand, and heart.

Accordingly, many educators (such as Dewey, Apple, and Galtung, among others) maintain that education is neutral, not political. However, education is political because of the very nature that education has goals and social purposes that it intends to foster among youth. In a specific direction, the questions asked direct learning. The material teachers choose to teach directs the classroom discussion toward a specific sphere. By presenting education as impartial, many educators indoctrinate learners into capitalist and market ideology schooling, competitiveness and aggression, and neoliberalism, and corruption without allowing students to challenge the masked agenda (Apple 1969; Freire 1970; Giroux 1981, 2006; McLaren 1989). Education is open to confronting, understanding and resisting violence. However, because basic education is clear with its goals, it is not an indoctrination process (Mayor 2005). It doesn't pour knowledge into students ' minds or say what to do to students. Nor does it use an expert program that comes into the classroom to tell students what to worry about. Education helps students start to ask questions and provides students with the resources they need to guide their learning. It's an education for thinking, not learning. It calls for why it is important in an electoral process to promote peace.

Inquiry-led education helps inspire students to ask themselves questions and to become reflective and involved learners. Engagement with issues at the core of contemporary society is the message students receive as they begin to ask critical questions in the classroom and participate actively in their communities. Students come to understand that the medium - the structure of learning - is the message. Value a variety of points of view, be confident, speak up, respectfully share opinions, resolve conflict dialogically, and reflect — these are the lessons students learn (Boulding,1988). Through this inquiry-based method of learning, sharing of personal knowledge and experiences, asking critical questions, and listening actively to others, students experience a range of thoughts and perspectives for cultural understanding, non-violent communication and conflict management. Youth begin to see old events, peoples, experiences, and structures in a new light. They begin to question their previous assumptions and values. This transformative education is required to cultivate a culture of peace. The way students see themselves, their families, and the world is changed by reflection and conversation. By introducing border children and young people to them, peaceful citizens could be raised (Reardon, 2001).

Therefore, education became necessary for every member of society. Nigeria has been a signatory to many international organizations, where adequate provisions of education to members are of paramount value. Based on these the Federal Government of Nigeria came up with a different educational program to provide adequate, qualitative, assessable, and affordable basic education (FGN, 2004).

But the question raised by many scholars is "How accessible is education to every school-age child in Nigeria?" This question is not unconnected with the Federal Ministry of Education (2018) report which shows that Nigeria, as in 2018, has about 54,434 public primary schools, 7,129 junior secondary schools, 18,238 private secondary schools, and over 153 Universities as at 2019. These schools are inadequate for a population of about 180 million people when compared with other developing countries like Ghana with a total population of $24,791,073$, which is one-seventh $(1 / 7)$ of the Nigerian population (Omundi index, 2012). Ghana is reported to have a total of 
51 Universities. This implies that more Ghanaians have access to tertiary education than Nigerians.

In that case, assess to qualitative education becomes a privilege in Nigerian rather than the right of every school-age child. By implication, so many school-age children are educationally disadvantaged. Tuohy (1999) considers being educationally disadvantaged as being denied access to or the result of the discontinuity between the school and non-school experience of a child. Such discontinuity springs up from culture and other socio-economic factors which involve not only the child's inability to cope with school but rather the school's inability to cope with the needs of the disadvantaged child, such as the school-age child of the Nigerian international border communities. The children in the border areas have little or no educational opportunities due to their locale which is the international border community.

Evidence and various reports from Border Community Development Agency (BCDA, 2010) revealed that schooling in the Nigerian border communities is confronted with many challenges which make the education to be of low quality. Mayor (2005) characterized as turning out political thugs that are always manipulated by politicians during the electoral process. Border communities are characterized by a lack of social amenities or infrastructures, such as inadequate health care facilities, a high rate of infant mortality and lack of good drinking water. Singh and Rangnekar (2000) describe the social sectors in the border areas, especially education and health, as suffering from serious deficiencies in terms of adequate infrastructure and service delivery which in turn influence the quality of education system in the area. The scarcity of teachers and absenteeism are still common characteristics of the education system of border areas. The dropout rate among school children, especially girls, is on the increase.

Perception is the process by which an individual comes to know and think about others and their work/duties, their characteristic qualities, their roles and functions in the society. In other words, when several individuals confront an object in their environment, the input of information that impinges on their respective sense organs, e.g. eyes, ears, etc. is the same for every individual, though they might have viewed it differently (International Encyclopaedia of Social Sciences, 1992). Also, it could be seen as a function of the accumulated experience of a man about the world of objects and people in his environment as a result of the difference in the perceptual functions among individuals, classes of individuals and within the same individual.

There are many features of an individual that may influence or define the perception of an individual. These include status, social class, occupation of an individual, gender, level of education attainment, location of residence (metropolitan or rural), and age, among others. These characteristics can influence the perception of members (such as teachers and other community members) in the business of education in the border areas of Nigeria on the state of education in their community.

Western education is perceived as the golden key to a brighter future, improved employment prospects and earnings. It is fundamental to a system that serves to stimulate individual talents to the fullest regardless of race, gender, social status, and locale. Border communities suffer neglect in almost all spheres of life. The Border Communities Development Agency (2010) reports that a visit to border villages of some states in Nigeria revealed that complete neglect is a general phenomenon affecting all border settlements in the country, thus, making them unsafe during an election. This has made the communities be at a disadvantage, educationally. Ekong's (2010) study 
attributes these disadvantages to the fact that the border areas are undeveloped. He stresses that the situation is so bad that some border communities in Gamboru Ngalla's local government area of Borno State migrated to the Cameroon Republic to access essential social amenities and education.

The findings of various studies such as that of the Central Bank of Nigeria (2000), Luka (2005), Folami and Karimu (2010) and Yusuf, Amali, and Ajidagba (2011) revealed that children in the border communities have little or no access to quality basic education, their education is characterized by lack of basic facilities and low quality, which in a way does not help in the promotion of peace and security needed in an electoral process. None of these studies was carried out in the North-Western part of Nigeria and none had studied the variables of education, peace and security and electoral process as its main variables. This constitutes a research gap to be filled by the study.

The study investigated the perception of community members on educating border dwellers as a catalyst for promoting peace and security in the Electoral Process. In specific terms, the study investigated:

a. Educating border dwellers as a catalyst for promoting peace and security in the electoral process as perceived by the community members

b. Whether there are differences in the perception of community members on educating border dwellers as a catalyst for promoting peace and security in the Electoral process based on gender.

c. Whether there are differences in the perception of community members on educating border dwellers as a catalyst for promoting peace and security in the Electoral process based on status.

The study addressed the following research questions:

a. What is the perception of community members on educating border dwellers as a catalyst for promoting peace and security in the Electoral process?

b. Is there any difference in the perception of community members on educating border dwellers as a catalyst for promoting peace and security in the Electoral process based on gender?

c. Are there differences in the perception of community members on educating border dwellers as a catalyst for promoting peace and security in the Electoral process based on status?

Based on the research purpose and questions, the following hypotheses were generated and tested:

Ho1: There is no significant difference in the perception of community members on educating border dwellers as a catalyst for promoting peace and security in the Electoral process based on gender.

Ho2 There are no significant differences in the perception of community members on educating border dwellers as a catalyst for promoting peace and security in the Electoral process based on status.

\section{RESEARCH METHOD}

The study employs a descriptive type of survey of an investigation into the perception of community members of whether by providing basic education to border 
dwellers it will help to promote peace and security needed in an electoral process. According to Oyeku and Ayodele (2010), this design is a systematic attempt to describe the characteristics of a given population or areas of interest, factually. The choice of the descriptive survey is also in line with Sambo (2008), who states that descriptive research aims at estimating as precisely as possible the attributes of a population. The population for this study was all community members residing in the international border areas of Zamfara State, Nigeria. The target population for the study was all the adult community members residing in border areas of Gurbin bore in Zurumi Loacl Government Areas of Zamfara State. There are total of 216,534 population comprises of teachers, community heads, and other male and female adults' members of the community. A total of 384 respondents out of a total population of 216,534 (National Bureau of Statistics, 2018). The sampling of 384 was in line with the Research Advisor (2006) table for sample selection, where it was pointed out that, in a population of 110,000-250,000 the most appropriate sample selection should be 384 at $95 \%$ level of confidence and $5.0 \%$ margin of error.

A - 12 items four-point-Likert scale researcher's designed questionnaire was used to elicit the needed data from the respondents. The questionnaire items were validated by experts in the Educational Research Measurement and Evaluation Unit of the Department of Social Sciences Education, Faculty of Education, the University of Ilorin to ensure its content validity of 0.61. This is in line with Sambo (2008) who maintained that the best procedure for validating a research instrument is to give it to a panel of experts. A test- retest reliability method was carried out with a sample of 45 border dwellers in the Araba village of Ilala local government area of Sokoto border community. A three-week interval period was given. The scores of the first were correlated with the scores of the second using Pearson's Product-Moment Correlation Coefficient and a reliability index of 0.87 was obtained. The questionnaire contained two sections. Bio-data of the respondent constituted (i.e gender and status) the first section while the second contained 12 items with 4 points responses (Strongly Agreed (4), Agreed (3), Disagree (2) and Strongly Disagree (1). The questionnaire was administered to the respondents by the researcher in the company of trained research assistants. The data collected was analyzed using average mean score, with 2.50 an accepted mean, Standard Deviation and t-test was used to test the two hypotheses at 0.05 alpha level.

\section{RESULTS AND DISCUSSION}

The research questions are answered as followed:

Research Question: What is the perception of community members on educating border dwellers as a catalyst for promoting peace and security in Electoral?

Table 1: showing the mean score and standard deviation.

\begin{tabular}{lllll}
\hline S/N & Statement & Mean & SD & Remark \\
\hline 1 & $\begin{array}{l}\text { Government provision of basic education in the border } \\
\text { community will give border dwellers the opportunity to } \\
\text { participate actively in the electoral process. }\end{array}$ & 3.64 & 1.24 & Agree \\
2 & $\begin{array}{l}\text { With basic education, children and youth living in the } \\
\text { 3ith }\end{array}$ & & & \\
\hline
\end{tabular}


border community will acquire the desired knowledge needed to bring about peace and security during the electoral process

3 Basic education to border dwellers, children and youth will develop a better understanding of skill, interest and positive attitude needed to promote peace and security during the electoral process.

4 Basic education in the border community will bring about the attitudinal change needed to cultivate a culture of peace needed in an electoral process.

5 Educating border dwellers help to develop a climate, within the school or another learning environment that will model peaceful and rights-respectful behaviour in the children and youth thus, promoting a peaceful electoral process.

6 Children of the border dwellers will be exposed to peaceful living through some of the teaching and learning techniques adopted by school teachers, thus promoting the culture of peace and security in an electoral process.

7 Educating border children and youth prepares them for 'lifelong learning' needed for survival and contribute positively to their society.

8 Basic education in Nigeria sought to produce individuals that can read, write and communicate effectively needed in the promotion of a culture of peace.

9 Educating every category of border dwellers especially people with special needs is required to breed youth who will imbibe the culture of peace in the society during an electoral process.

10 Educating border children and youth allows them to think critically about issues and make valuable

$2.91 \quad 1.23 \quad$ Agree

$3.10 \quad 1.27 \quad$ Agree

$4.21 \quad 2.63 \quad$ Agree

$3.15 \quad 1.20$ Agree

$3.72 \quad 1.40 \quad$ Agree decisions about maintaining peace and security in an electoral

11 Educating border children and youth bring about positive transformation in the community.

12 Educating border dwellers helps learners begin to raise questions and gives students the tools they need to direct their learning.

Table one revealed the mean score of community members ranging from 2.91 to 4.21, meaning that all the border dwellers perceive educating them especially their children and youth as a welcome development that would help in breeding youth who would build up peace culture that is needed in an electoral process.

Hypotheses One: There is no significant difference in the perception of community members on educating border dwellers as a catalyst for promoting peace and security in the Electoral process on the basis of gender. 
SPEKTA

Jurnal Pengabdian Kepada Masyarakat : Teknologi dan Aplikasi

Vol. 1, No. 2, Desember 2020

Table 3: showing t-test analysis of respondent on the basis of gender

\begin{tabular}{llllllll}
\hline Gender & N & Mean & $\begin{array}{l}\text { Std. } \\
\text { Deviation }\end{array}$ & df & t-test & Sig (2-tail) & Decision \\
\hline Male & 264 & 33.22 & 3.61 & 382 & 0.31 & 0.75 & Not rejected \\
Female & 120 & 33.19 & 4.55 & & & & \\
\hline
\end{tabular}

$\mathrm{P}=0.05$

Table 2 shows t-value $=-0.30$ with $\mathrm{P}$-value $=0.971>0.05$ alpha level. Since 0.97 is greater than 0.05 alpha level, hypotheses one is thus not rejected. This indicates that there is no significant difference in the perception of the male and female members of the border communities on educating border youth and children as a catalyst for promoting peace and security in the electoral process.

Hypotheses Two: There is no significant difference in the perception of community members on educating border dwellers as a catalyst for promoting peace and security in the Electoral process based on status.

Table 2: showing t-test analysis of respondent on the basis of status

\begin{tabular}{lcclllll}
\hline Status & N & Mean & $\begin{array}{l}\text { Std. } \\
\text { Deviation }\end{array}$ & df & t-test & Sig (2-tail) & Decision \\
\hline Teachers & 12 & 33.25 & 3.64 & 382 & -0.030 & 0.97 & $\begin{array}{l}\text { Not } \\
\text { Rejected }\end{array}$ \\
$\begin{array}{l}\text { Border } \\
\begin{array}{l}\text { community } \\
\text { members }\end{array}\end{array}$ & 372 & 33.28 & 3.93 & & & & \\
\hline
\end{tabular}

$\mathrm{P}=0.05$

Table 3 shows t-value $=0.31$ with $\mathrm{P}$-value $=0.75>0.05$ alpha level. Since 0.75 is greater than 0.05 alpha level, hypotheses two is accepted. This implies that both teachers and all members of the communities (Farmers, village heads, Islamic scholars, shop-owners among others) do not differ in their perception of educating border dwellers as a catalyst for promoting peace and security in the areas.

\section{Summary of the Findings}

The findings in this study were summarized as follows:

1. All the sample community members in the border areas perceived educating border dweller which includes children and youth as a catalyst to promoting peace and security in an electoral process.

2. The study also revealed that difference does not exist in the perception of all the community members on educating border dwellers as a catalyst for promoting peace and security in an electoral process based on both gender and status.

From the study, it was revealed that the government provision of basic education in the border community will give border dwellers the opportunity to be able to read, 
write and communicate effectively and participate actively in the electoral process. This is necessary because ideas will remain ideas if they are not well nurtured and communicated to the people in a way that the people can understand their meaning, significance and how the ideas should be used to better the lives of the people. Thus, literacy and the ability to communicate become central to all forms of development. Most of those involved in violence act during an election in Nigeria are ignorant, illiterate or school drop-out, they as a result of frustration and sees engagement in violence or the act of been used by a politician to cause violence during the electoral process as the lasting solution to their problems. With basic education, children and youth living in these border communities will acquire the desired knowledge needed to bring about peace and security during the electoral process.

Educating children and youth in the border communities offer youth an opportunity to develop a better understanding of skills and positive attitude which is required in breeding a patriotic citizen. Every nation requires patriotic citizens that can define the course of the nation, qualitative education has been producing individuals who have been contributing and are ready to contribute to the growth and development of the nation first by maintaining peace and security. Border children from their formative age would be trained on how to love their country first before even themselves, from different subjects they will be exposed to in the school. Therefore, been patriotic citizens will be able to promote peace and security during an electoral process. Children and youth in the border community after undergoing education develop a change of attitude was the perception of the border community members. This because the school itself is seen as a peace zone where the right character would be molded.

It was revealed from the study that giving adequate education to border dwellers is necessary since; education is overt with its intentions to confront, understand, and resist violence. Education helps learners begin to raise questions and gives students the tools they need to direct their learning. Education is about how to learn, not what to learn. This calls for why it is needed in the promotion of peace in an electoral process. Because education brings about transformation in the life of every human society, the border community will not be an exception. Border dweller needs qualitative education to be able to function effectively and promote the culture of peace and security needed in an electoral process.

\section{CONCLUSION}

In conclusion, educating children and youth in the border communities is considered necessary, in order to give border dwellers, the opportunity to participate actively in the electoral process. It will also afford them to acquire appropriate knowledge, values, skills, and behaviors needed to nurture a peace culture in their society and the nation at large. The content and teaching strategies adopted at all levels of education in the promotion of a culture of peace which is needed during an electoral process. Because of the nature of international border communities, border dwellers required not just education but qualitative education.

It is on the basis of these that, it was recommended that, the Nigerian government should provide qualitative education for people residing in the international border areas. Also, the type of education that will be provided for them should be suitable to their environment. Since the aim of education in every society is to cater to the needs and aspirations of the society where it is situated. 


\section{ACKNOWLEDGMENT}

Special acknowledgment goes to the village heads and the religious leaders of the border communities in the Gurbin bore community of Zurmi Local Government Areas of Zamfara State for their cooperation and support all through the process of data collection

\section{BIBLIOGRAPHY}

Aliu, S. (2001, January).The competitive drive, new technologies, and employment: the human capital link. Paper presented at the second tripartite conference of manpower planners. Chelsea Hotel, Abuja.

Apple, M. (1969). Ideology and curriculum. New York: Routledge. Freire 1970;

Boulding, E. (1988). Building a global civic culture: Education for an interdependent world. New York: Teachers College Press.

Central Bank of Nigeria (2000) in Rahji, M. A. Y. Primary school enrolment and gender gap of rural households' children in Southwestern Nigeria. Retrieved from: www.saga.cornell.edu/saga/educconf/rahji.pdf .

Denga, D.I. (1993). Education at a glance: From cradle to tomb. Calabar: Rapid Educational Publishers Ltd.

Denga. D. I. (1999). The eve of the 21st Century: Threshold education strategies for entry and sustainable development. Calabar: Rapid Educational Publishers. Ltd.

Ebong, J. M. (2006). Understanding the economics of education. Port Harcourt:Eagle Lithograph press.

Ekwuruke H.(2007). The State of Youth in Nigeria: What We Want? Nando Foundation Inc.

Federal Republic of Nigeria (2004). .National policy on education. Lagos: NERDC Press.

Federal Republic of Nigeria (2009). National Bureau of Statistics: Socialstatistics in Nigeria. Retrieved from:www.Nigeriapopulation.org

Folami, A. O. \& Karimu, O. O. (2010, June 21). Climate change and cross-border crime in Nigeria. Paper presented at the $250^{\text {th }}$ Anniversary Conference Organized for the Royal Norwegian Society of Sciences and Letter on Climate Change and Security in Trondheim, Norway.

Freire, P. (1970). Pedagogy of the oppressed. New York: Continuum Publishing.

Giroux, H. (2006). Stormy weather: Hurricane Katrina and the politics of disability. Boulder, CO: Paradigm Publishers.

Laogun, E. A. (2002). "Rural Youth Training Needs for Rural Community Development." Nigerian Journal of Rural Sociology, 3,2, 57-63.

Luka, E.O. (2005). Border people and the national economy. Research submitted to the international community foundation: Blurred boundaries, trans-boundary impacts, and solutions in the San Diego-Tijuana border region. Retrieved from: www.icfdn.org/publications/blurredborders/documents/execsummary.pdf

Mayor, F. (2005). Democracy, nonviolence, and peace. In The Earth Charter inAction: Toward a Sustainable World, edited by Peter Blaze Corcoran, Mirian Vilela, and Alide Roerink, 117-119. Amsterdam: KIT Publishers.

McLaren, P. (1989). Life in schools. New York: Longman.

Olujide, M.G. (1999). "The Role of Nigerian Integrated Rural Accelerated Development Organisation (NIRADO) in Farm Children Development in Lagos State." Technical Report of NIRADO, Lagos, pp. 1-37. 
Olujide, M. G (2008). The attitude of Youth Towards Rural Development Projects in Lagos State, Nigeria.Journal of SocialSciences, 17,2, 163-167

Omundi index (2012). Ghana Demographics Profile 2012.Retrieved from: wwwfile://C201\%20demographics_profile.html.

Oyeku, E. A. \& Ayodele, O.O. (2010). Research Methodology. Ogun: Merci Production.

Price, F. (2005). The Bakassi peninsula: the border dispute between Nigeria and Cameroon. Retrieved from: www.icjcij.org/icjwww/ipresscom/ipress2002/ipresscom200226_20021010.h tm.

Preyekuro I. \& Agnes, E. M.(2011). Youths, electoral violence and democratic consolidation in Nigeria. Anthropologist, 13,3,217-225

Reardon, B.(2001). Education for a culture of peace from a gender perspective. Paris: UNESCO.

Sambo, A. A. (2008). Research methods in education. Edo: Stirling-Horden Publishers.

Singh, K. \& Rangnekar, U.S. (2000). A profile report on a pre-project survey of border area development programmes in developing countries. Retrieved from: www.pbplanning.gov.in/pdf/Annexure-VI.pdf.

Swastik N. (2014). Notes on the true Meaning, Definition, and Concept of Education. retrieved from:www.preservearticles.com/201105056299/meaning-anddefinition-and-concept-of-education.htm

The Research Advisors (2006). Sample size table. Retrieved from: http://researchadvisors.com.

Yusuf, A., Amali, I. O. O. \& Ajidagba, U. A. (2011).Teachers' assessment of the quality of the basic education in the border area of Kwara State, Nigeria. African Journal of Historical Sciences in Education.7,2, 60-67. 
SPEKTA

Jurnal Pengabdian Kepada Masyarakat : Teknologi dan Aplikasi

Vol. 1, No. 2, Desember 2020

This page is intentionally left blank 